https://helda.helsinki.fi

\title{
Trees as carbon sinks and sources in the European Union
}

\section{Liski, J.}

Elsevier

2000

Liski, J. et al. 2000. Trees as carbon sinks and sources in the European Union.

Environmental Science \& Policy 3 (2000) 91-97.

http://hdl.handle.net/1975/172

Downloaded from Helda, University of Helsinki institutional repository.

This is an electronic reprint of the original article.

This reprint may differ from the original in pagination and typographic detail.

Please cite the original version. 


\title{
Trees as carbon sinks and sources in the European Union
}

\author{
J. Liski $^{\text {a,* }}{ }^{2}$ T. Karjalainen ${ }^{\text {a }}$, A. Pussinen ${ }^{\text {a }}$, G.-J. Nabuurs ${ }^{\text {b }}$, P. Kauppi ${ }^{\text {c }}$ \\ ${ }^{a}$ European Forest Institute, Torikatu 34, FIN-80100, Joensuu, Finland \\ ${ }^{\mathrm{b}}$ Institute for Forestry and Nature Research, Postbus 23, NL-6700 AA, Wageningen, The Netherlands \\ ${ }^{\mathrm{c}}$ Department of Limnology and Environmental Protection, PO Box 27, FIN-00014, University of Helsinki, Helsinki, Finland
}

\begin{abstract}
The carbon (C) sinks and sources of trees that may be accounted for under Article 3.3 of the Kyoto Protocol during the first commitment period from 2008 to 2012 were estimated for the countries of the European Union (EU) based on existing forest inventory data. Two sets of definitions for the accounted activities, afforestation, reforestation and deforestation, were applied. Applying the definitions by the Food and Agricultural Organization of the United Nations (FAO), the trees were estimated to be a $\mathrm{C}$ source in eight and a $\mathrm{C}$ sink in seven countries, and in the whole $\mathrm{EU}$ a $\mathrm{C}$ source of $5.4 \mathrm{Tg} \mathrm{year}^{-1}$. Applying the definitions by the Intergovernmental Panel of Climate Change (IPCC), the trees were estimated to be a $\mathrm{C}$ source in three and a $\mathrm{C}$ sink in 12 countries, and in the whole EU a C sink of $0.1 \mathrm{Tg}_{\text {year }}{ }^{-1}$. These estimates are small compared with the $\mathrm{C}$ sink of trees in all EU forests, $63 \mathrm{Tg}_{\text {year }}{ }^{-1}$, the anthropogenic $\mathrm{CO}_{2}$ emissions of the $\mathrm{EU}, 880 \mathrm{Tg} \mathrm{C}$ year ${ }^{-1}$, and the reduction target of the $\mathrm{CO}_{2}$ emissions, $8 \%$. In individual countries, the estimated $\mathrm{C}$ sink of the trees accounted for under Article 3.3 was at largest $8 \%$ and the $\mathrm{C}$ source $12 \%$ compared with the $\mathrm{CO}_{2}$ emissions. (C) 2000 Elsevier Science Ltd. All rights reserved.
\end{abstract}

Keywords: Kyoto Protocol; Article 3.3; Carbon sink; Carbon source; Stock change; Forest; $\mathrm{CO}_{2}$ emission; Afforestation; Reforestation; Deforestation

\section{Introduction}

Forests play an important role in the global $\mathrm{C}$ cycle. Forest soils have been estimated to contain $790 \mathrm{Pg} \mathrm{C}$, an amount comparable with that in the present atmosphere, and forest vegetation $360 \mathrm{Pg} \mathrm{C}$, an amount comparable with about half of that in the atmosphere and the soils (Dixon et al., 1994; Schimel, 1995). The $\mathrm{C}$ in forests originates from the atmosphere, and it continuously cycles between forests and the atmosphere. Thus, changing $\mathrm{C}$ stocks in forests can affect the amount of $\mathrm{C}$ in the atmosphere. If more $\mathrm{C}$ accumulates in forests, they are a sink for atmospheric C. If the $\mathrm{C}$ stocks in forests decrease releasing $\mathrm{C}$ into the atmosphere, the forests are a source of atmospheric

\footnotetext{
* Corresponding author. Tel.: +358-13-252020; fax +358-13124393.

E-mail address: jari.liski@efi.fi (J. Liski).
}

C. The $\mathrm{C}$ stocks of forests can change in two ways, on the one hand as a result of changes in forest area and on the other hand as a result of changes in the $\mathrm{C}$ stocks on the existing forest area.

The importance of forests for atmospheric $\mathrm{CO}_{2}$ levels was acknowledged as countries negotiated about their quantified reduction commitments of greenhouse gas emissions in Kyoto in December 1997. According to Article 3.3. of the agreed Kyoto Protocol, some $\mathrm{CO}_{2}$ sources and sinks of forests "shall be used to meet the commitments" (UNFCCC, 1997a). The sources and sinks to be used were restricted to those "resulting from direct human-induced land-use change and forestry activities, limited to afforestation, reforestation and deforestation since 1990, measured as verifiable changes in C stocks in each commitment period".

The $\mathrm{CO}_{2}$ sinks and sources of forests in Article 3.3. of the Kyoto Protocol have occasioned discussion and been subject to criticism (e.g. IGBP Terrestrial Carbon Working Group, 1998). The interpretation of the 


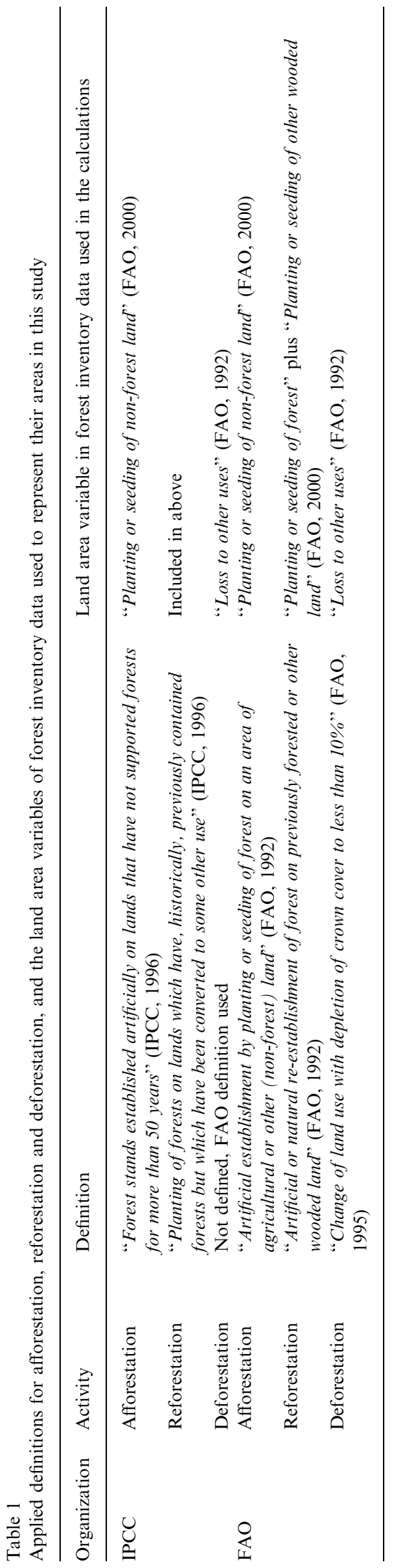

article has not been unanimous. Several views have been presented with respect to the meaning of afforestation, reforestation and deforestation and how the associated C stocks could be accounted for (e.g. Schlamadinger and Marland, 1998; Lund, 1999). The article has been said to provide possibilities to increase cumulative emissions from forests, because it accounts for the $\mathrm{C}$ budget of forests only partially and over discontinuous time periods. This would be contradictory to the objectives of the United Nations Framework Convention on Climate Change (UNFCCC) and limit the effectiveness of the whole protocol. It has been claimed that the share of forests and their $\mathrm{C}$ sinks and sources the article accounts for are small, although this share and the effect of applying different afforestation, reforestation and deforestation definitions on the $\mathrm{C}$ sinks and sources have been quantified only for a few countries (Mäkipää and Tomppo, 1998; Ford-Robertson et al., 1999; Karjalainen et al., 2000; Nabuurs et al., 1999).

To implement the Kyoto Protocol successfully, the consequences of different ways of interpreting Article 3.3. need to be understood. The objectives of the present study are to demonstrate in EU countries (1) how the $\mathrm{C}$ sinks and sources of trees that may be accounted for under Article 3.3 of the Kyoto Protocol during the first commitment period from 2008 to 2012 will depend on the applied definition for afforestation, reforestation and deforestation, (2) how these values will differ from the $\mathrm{C}$ sink of trees in all forests, and (3) how they will relate to anthropogenic $\mathrm{CO}_{2}$ emissions.

\section{Materials and methods}

The definitions for afforestation, reforestation and deforestation we applied to estimate the $\mathrm{C}$ sinks and sources of trees that may be accounted for under Article 3.3. of the Kyoto Protocol were those used by IPCC and FAO (Table 1). IPCC and FAO provide different definitions for afforestation and reforestation but only FAO provides a definition for deforestation. We used this deforestation definition also in our IPCC calculation.

The $\mathrm{C}$ sinks and sources of trees accounted for under Article 3.3 of the Kyoto Protocol during the first commitment period from 2008 to 2012 applying these definitions were estimated for each EU country. The estimates were based on the latest international forest inventory data (FAO, 1992, 2000). The land area data in the earlier forest inventory report (FAO, 1992) is for the 1980s and those in the more recent one (FAO, 2000) for the early and mid 1990s. The present tree $\mathrm{C}$ estimates include $\mathrm{C}$ in woody biomass, i.e. wood, bark, branches, twigs, stumps and roots of trees, alive and dead, shrubs and bushes (FAO, 2000). 
All forests mean forests on all forest and other wooded land.

The area of "planting or seeding of non-forest land" (FAO, 2000), La (ha year ${ }^{-1}$ ), was taken to represent the annual area of human-induced afforestation and reforestation according to IPCC definitions and the annual area of afforestation according to FAO definition (Table 1). The estimate for the annual increase in the $\mathrm{C}$ stock of trees on such land between 2008 and 2012, $B a\left(\mathrm{Mg} \mathrm{C}_{\text {year }}{ }^{-1}\right)$, was calculated as

$B a=t \times L a \times I$,

where $t$ is the time since 1990 until the middle of the first commitment period (20 years) and $I$ the average net annual increment of tree biomass on forest and other wooded land $\left(\mathrm{Mg} \mathrm{C} \mathrm{ha}{ }^{-1}\right.$ year $\left.^{-1}\right) . t \times L a$ represents the cumulative land area under the activities since 1990 until the middle of the first commitment period. $I$ was taken from the FAO report (2000).

The sum of the areas of "planting or seeding of forest" and "planting or seeding of other wooded land" (FAO, 2000), $L r$ (ha year ${ }^{-1}$ ), was taken to represent the annual area of human-induced reforestation according to FAO definition (Table 1). The estimate for the annual change in the $\mathrm{C}$ stock of trees on such land between 2008 and 2012, $\mathrm{Br}\left(\mathrm{Mg} \mathrm{C}\right.$ year $\left.{ }^{-1}\right)$, was calculated as

$B r=t \times L r \times I-L r \times S$,

where $t$ is the time since 1990 until the middle of the first commitment period (20 years), $I$ the average net annual increment of tree biomass on forest and other wooded land $\left(\mathrm{Mg} \mathrm{C} \mathrm{ha}{ }^{-1}\right.$ year $\left.^{-1}\right)$ and $S$ the average tree biomass on forest and other wooded land $(\mathrm{Mg} \mathrm{C}$ $\left.\mathrm{ha}^{-1}\right) . t \times L r$ represents the cumulative reforestation area since 1990 until the middle of the first commitment period. The positive term represents the $\mathrm{C}$ sink of trees planted or seeded since 1990 and the negative term the $\mathrm{C}$ loss in trees harvested before reforestation during the commitment period. $I$ and $S$ were taken from the FAO report (2000).

The area of "loss to other uses" (FAO, 1992), Ld $\left(\right.$ ha year ${ }^{-1}$ ), was taken to represent the annual area of deforestation (Table 1). This area was not reported in the more recent forest inventory report (FAO, 2000). The estimate for the annual change in the $\mathrm{C}$ stock of trees on such land, $B d\left(\mathrm{Mg} \mathrm{C}\right.$ year $\left.{ }^{-1}\right)$, was calculated as

$B d=-L d \times S$,

where $S$ is the average tree biomass on forest and other wooded land $\left(\mathrm{Mg} \mathrm{C} \mathrm{ha}^{-1}\right) . S$ was taken from the FAO report (2000).

The annual change in the $\mathrm{C}$ stock of trees accounted for under Article 3.3 of the Kyoto Protocol during the first commitment period from 2008 to 2012 applying IPCC definitions, $B_{\text {IPCC }}\left(\mathrm{Tg} \mathrm{C}_{\mathrm{Cear}}{ }^{-1}\right)$, was calculated as

$B_{\mathrm{IPCC}}=B a+B d$,

and that by applying FAO definitions, $B_{\mathrm{FAO}}(\mathrm{Tg} \mathrm{C}$ year $\left.{ }^{-1}\right)$, as

$B_{\mathrm{FAO}}=B a+B r+B d$.

These stock changes were compared with the $\mathrm{C}$ sink of trees in all forests of the EU in the early 1990s (FAO, 2000) and the anthropogenic $\mathrm{CO}_{2}$ emissions of the EU in 1995 (UNFCCC, 1997b). The anthropogenic emissions included emissions from energy production, industrial processes, waste and other sources but excluded emissions from land-use change and forestry.

The present estimates of the $\mathrm{C}$ sinks and sources of trees accounted for under Article 3.3. of the Kyoto Protocol during the first commitment period from 2008 to 2012 must be considered rough. First, they are predictions of the future, which are uncertain by nature. Second, in calculating the estimates we needed to assume that the annual afforestation, reforestation and deforestation areas remain for the whole calculation period as they were reported in the latest forest inventory reports (FAO 1992, 2000). Any changes in the areas, change the $\mathrm{C}$ sinks and sources. Third, we used average growth rates to calculate the $\mathrm{C}$ sinks of afforestation and reforestation and average biomasses to calculate the $\mathrm{C}$ sources of reforestation and deforestation. Since the afforested and reforested stands to be accounted for will be young, using the average growth rate may overestimate their $\mathrm{C}$ sinks. Similarly, the average biomass does not necessarily represent tree

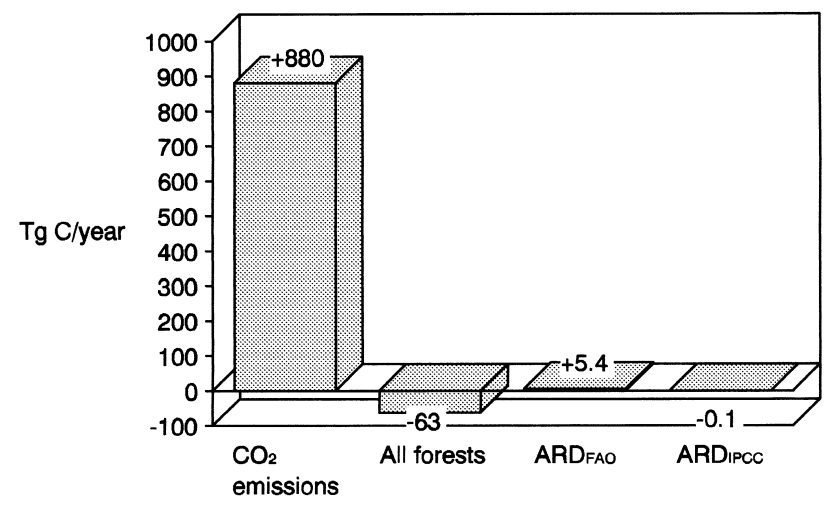

Fig. 1. Annual change in the carbon stock of trees accounted for under Article 3.3 of the Kyoto Protocol in the EU during the first commitment period from 2008 to 2012 applying IPCC (ARD IPCC $_{\text {) }}$ and FAO definitions $\left(\mathrm{ARD}_{\mathrm{FAO}}\right)$ for afforestation, reforestation and deforestation compared with the $\mathrm{C}$ sink of trees in all EU forests in the early 1990s (FAO, 2000) and the $\mathrm{CO}_{2}$ emissions of the $\mathrm{EU}$ in 1995 (UNFCCC, 1997b). Sinks for atmospheric C have a negative sign and sources of atmopsheric $\mathrm{C}$ a positive sign. 


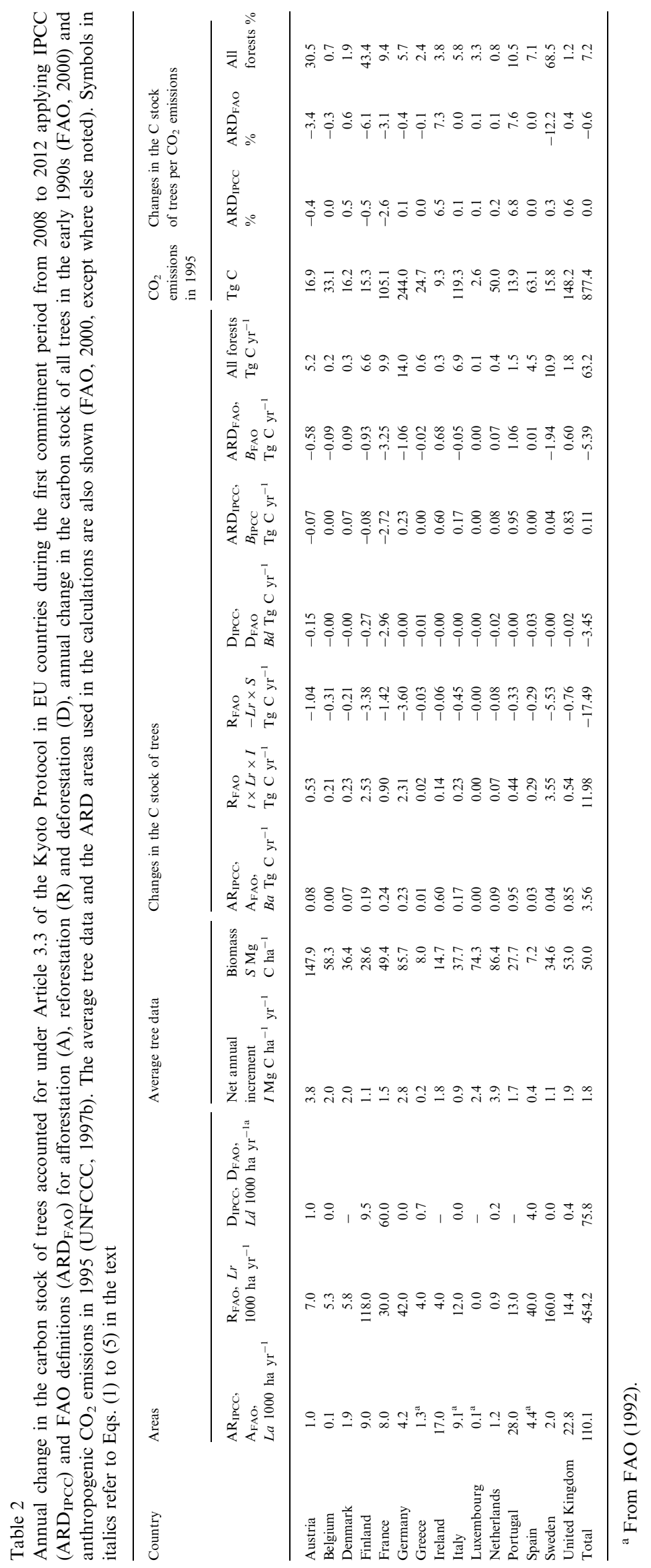


biomass before reforestation or deforestation. Despite these limitations, we think the estimates are appropriate for accomplishing the objectives of this study.

\section{Results}

In the EU as a whole during the first commitment period from 2008 to 2012, trees accounted for under Article 3.3 of the Kyoto Protocol applying FAO definitions were estimated to be a source for $\mathrm{C}$ of about 5.4 $\mathrm{Tg} \operatorname{year}^{-1}$ (Fig. 1). This was because the C losses on reforestation and deforestation areas, 17.5 and 3.5 $\mathrm{Tg}$ year $^{-1}$ respectively, were larger than the $\mathrm{C}$ sinks on afforestation and reforestation areas, 3.6 and $12.0 \mathrm{Tg}$ year $^{-1}$ respectively (Table 2). Applying IPCC definitions, the trees were estimated to be a $\mathrm{C}$ sink of 0.1 $\mathrm{Tg}$ year $^{-1}$ (Fig. 1). The balance was a result of the $\mathrm{C}$ losses on deforestation areas, $3.5 \mathrm{Tg}$ year $^{-1}$, being nearly as large as the $\mathrm{C}$ gains on afforestation and reforestation areas, $3.6 \mathrm{Tg}$ year $^{-1}$ (Table 2).

For both these scenarios, the changes in the $\mathrm{C}$ stocks of trees accounted for under Article 3.3 of the Kyoto Protocol were very different from the actual change in the $\mathrm{C}$ stock of trees in all forests. Accounting for all forests, tree growth exceeded harvesting in each country so that the $\mathrm{C}$ stock of trees in the EU increased as much as $63 \mathrm{Tg}_{\text {year }}{ }^{-1}$ (Fig. 1, Table 2).

In comparison with the anthropogenic $\mathrm{CO}_{2}$ emissions of the EU, $880 \mathrm{Tg} \mathrm{C}$ in 1995, the $\mathrm{C}$ sink of trees in all forests equalled about $7 \%$ of the emissions, while that accounted for under Article 3.3 of the Kyoto Protocol applying IPCC definitions was only $0.02 \%$ (Table 2). The $\mathrm{C}$ source of the trees applying FAO definitions was $0.6 \%$ compared with the emissions.

Applying FAO definitions, the trees accounted for under Article 3.3. of the Kyoto Protocol were estimated to be a $\mathrm{C}$ source in eight and a $\mathrm{C}$ sink in seven countries (Table 2). The fact that the trees constituted a $\mathrm{C}$ source was mostly an effect of reforestation: the $\mathrm{C}$ loss in trees harvested before reforestation during the commitment period appeared to be larger than the $\mathrm{C}$ gain in regrowing trees since 1990. The estimated C source of reforestation was large in countries where the average tree biomass per forest area was large relative to the average growth rate of trees. Such countries were Austria, Belgium, Finland, Germany, Italy and Sweden. In France, the $\mathrm{C}$ source was due to a large reported deforestation area. The trees being a $\mathrm{C}$ sink was, in turn, mainly an effect of afforestation. The estimated $\mathrm{C}$ sink of afforestation was larger than the $\mathrm{C}$ source of reforestation in countries where the average growth rate of trees was high relative to the average tree biomass per forest area. This was the case in Denmark, Greece, Ireland, Luxembourg, the Netherlands,
Portugal, Spain and the United Kingdom. Compared with anthropogenic $\mathrm{CO}_{2}$ emissions, the net $\mathrm{C}$ source of the trees was largest, $3-12 \%$ of the emissions, in Sweden, Finland, Austria and France. The net $\mathrm{C}$ sink was clearly largest compared with the emissions in Portugal and Ireland where it was about $7 \%$ of the emissions.

Applying IPCC definitions, the trees accounted for under Article 3.3 of the Kyoto Protocol were estimated to cover a substantial proportion of the $\mathrm{C}$ sink of trees in all forests in countries where the $\mathrm{C}$ sink of trees in all forests was relatively small (Table 2). In Denmark they covered $25 \%$, in the Netherlands $19 \%$, in Portugal $65 \%$ and in the United Kingdom $46 \%$. In Ireland, the $\mathrm{C}$ sink of trees accounted for under Article 3.3. of the Kyoto Protocol was even estimated to be $72 \%$ larger than the $\mathrm{C}$ sink of trees in all forests in early 1990s. On the other hand, in countries where the C sink of trees in all forests was large, the trees accounted for under Article 3.3 of the Kyoto Protocol were estimated to be only a negligible $\mathrm{C}$ sink or source. In Sweden, the $\mathrm{C}$ sink of the trees accounted for under Article 3.3 of the Kyoto Protocol was $0.4 \%$ of the $\mathrm{C}$ sink of trees in all forests, in Germany this proportion was $1.6 \%$. In Austria, Finland and France, the trees accounted for under Article 3.3. of the Kyoto Protocol were estimated to be a $\mathrm{C}$ source. Compared with anthropogenic $\mathrm{CO}_{2}$ emissions, the $\mathrm{C}$ sink of trees accounted for under Article 3.3. of the Kyoto Protocol was clearly largest, $7 \%$ of the emissions, in Ireland and Portugal (Table 2).

\section{Discussion}

In the $\mathrm{EU}$ as a whole, the changes in the $\mathrm{C}$ stock of trees accounted for under Article 3.3. of the Kyoto Protocol applying both studied definitions for afforestation, reforestation and deforestation were negligible compared with the $\mathrm{C}$ sink of trees in all forests and anthropogenic $\mathrm{CO}_{2}$ emissions. In contrast, the $\mathrm{C}$ sink of trees in all forests was as much as 7\% compared with the emissions. This is about as much as the emission reduction target of the EU in the Kyoto Protocol, $8 \%$ of the emissions in 1990 (UNFCCC, 1997a). Thus, the $\mathrm{C}$ sink of trees in all forests may be considered as important for the atmospheric $\mathrm{CO}_{2}$ concentration as the targeted emission reduction while the $\mathrm{C}$ budget of trees accounted for under Article 3.3. of the Kyoto Protocol with past afforestation, reforestation and deforestation rates seems unimportant.

The $\mathrm{C}$ sinks and sources of trees accounted for under Article 3.3. of the Kyoto Protocol may still be important for the $\mathrm{C}$ budget of individual countries. The $\mathrm{C}$ sink applying IPCC definitions for afforestation, reforestation and deforestation can be large in countries where the present forest area is relatively 
small, leaving substantial areas available for afforestation and reforestation. For example, in Ireland and Portugal, the $\mathrm{C}$ sink of trees accounted for under Article 3.3. of the Kyoto Protocol was estimated to be equal to $7 \%$ of the anthropogenic $\mathrm{CO}_{2}$ emissions. Interpreting afforestation, reforestation and deforestation according to FAO definitions did not change the result for these two countries. For some other countries it did. Trees accounted for under Article 3.3 of the Kyoto Protocol applying FAO definitions were estimated to be a $\mathrm{C}$ source comparable with $3-12 \%$ of anthropogenic $\mathrm{CO}_{2}$ emissions in Austria, Finland, France and Sweden. This would, accordingly, increase the need for reducing $\mathrm{CO}_{2}$ emissions in these countries to meet the emission reduction targets.

The $\mathrm{C}$ budget of trees accounted for under Article 3.3. of the Kyoto Protocol was related to the $\mathrm{C}$ balance of trees in all forests only very weakly. If anything, the correlation tended to be negative. In countries where the $\mathrm{C}$ sink of trees in all forests was large, in Austria, Finland, France, Germany, Italy and Sweden, the $\mathrm{C}$ sink of trees accounted for under Article 3.3. of the Kyoto Protocol was negligible or the trees were even a $\mathrm{C}$ source. Thus, Article 3.3 seems irrelevant for the management of forests in these countries, which account for $85 \%$ of the actual C sink of trees in all forests of the EU.

The $\mathrm{C}$ sinks and sources of trees on afforestation, reforestation and deforestation areas may play a different role in the $\mathrm{C}$ budget elsewhere in the world than in the EU. Afforestation of marginal pastures has been estimated to make a significant contribution to meeting the national obligations of the Kyoto Protocol in New Zealand (Ford-Robertson et al., 1999). Considering the estimated huge $\mathrm{C}$ emissions from deforestation in the tropics, 1.6 $\mathrm{Pg} \mathrm{C}$ year $^{-1}$ (Dixon et al., 1994), stopping deforestation and increasing afforestation are certainly important on a world scale.

The present figures of the $\mathrm{C}$ sinks and sources of trees accounted for under Article 3.3. of the Kyoto Protocol during the first commitment period from 2008 to 2012 in the EU must be considered as rough estimates, as already discussed in Section 2 of this paper. Despite these limitations, we think they demonstrate how the $\mathrm{C}$ sinks and sources of trees accounted for under Article 3.3. of the Kyoto Protocol depend on the applied definition for afforestation, reforestation and deforestation, differ from the $\mathrm{C}$ sink of trees in all forests and relate to anthropogenic $\mathrm{CO}_{2}$ emissions in the whole EU and individual EU countries.

\section{Acknowledgements}

This study was a part of the European Topic Centre Nature Conservation Work done for the report "The
Environment in the EU at the Turn of the Century" published by the European Environment Agency (EEA). We thank Andre Jol at the EEA for his comments, Christopher F.L. Prins at UN-ECE/FAO for his help with the forest inventory data and reviewers Eveline Trines, Piers Maclaren and Raisa Mäkipää for their constructive criticism and suggestions for improvement.

\section{References}

Dixon, R.K., Brown, S., Houghton, R.A., Solomon, A.M., Trexler, M.C., Wisniewski, J., 1994. Carbon pools and flux of global forest ecosystems. Science 263, 185-190.

FAO, 1992. The forest resources of temperate zones. The UN-ECE/ FAO 1990 Forest Resource Assessment, vol. 1, General Forest Resource Information. United Nations, New York.

FAO, 1995. Forest resources assessment 1990: global synthesis. Forestry Paper, vol. 124. FAO, Rome.

FAO, 2000. Forest Resources of Europe, CIS, North America, Australia, Japan and New Zealand (industrialized temperate/boreal countries), UN-ECE/FAO Contribution to the Global Forest Resources Assessment 2000, Main Report. United Nations, New York and Geneva (in press).

Ford-Robertson, J., Robertson, K., Maclaren, P., 1999. Modelling the effect of land-use practices on greenhouse-gas emissions and sinks in New Zealand. Environmental Science and Policy 2, 135144.

IGBP Terrestrial Carbon Working Group, 1998. Terrestrial carbon cycle: implications for the Kyoto Protocol. Science 280, 13931394.

IPCC, 1996. Revised 1996 IPCC Guidelines for National Greenhouse Gas Inventories, vol. 1, Reporting Instructions. UK Meteorological Office, Bracknell.

Karjalainen, T., Liski, J., Pussinen, A., Lapveteläinen, T., 2000. Sinks in the Kyoto Protocol and Considerations for Ongoing Work in the UNFCCC work. The Nordic Ministry Council (in press).

Lund, G.H., 1999. A 'forest' by another name .... Environmental Science and Policy 2, 125-133.

Mäkipää, R., Tomppo, E., 1998. Suomen metsät ovat hiilinielu — vaikka Kioton ilmastosopimuksen mukaan muulta näyttää. Metsätieteen aikakauskirja 2/1998, 268-274 (in Finnish).

Nabuurs, G.J., Dolman, A.J., Verkaik, E., Whitmoore, A.P., Daamen, W.P., Oenema, O., Kabat, P., Mohren, G.M.J., 1999. Resolving Issues on Terrestrial Biospheric Sinks in the Kyoto Protocol. Dutch National Research Programme on Global Air Pollution and Climate Change Report 410200030.

Schimel, D.S., 1995. Terrestrial ecosystems and the carbon cycle. Global Change Biology 1, 77-91.

Schlamadinger, B., Marland, G., 1998. The Kyoto Protocol: provisions and unresolved issues relevant to land-use change and forestry. Environmental Science and Policy 1, 313-327.

UNFCCC, 1997a. Kyoto Protocol to the United Nations Framework Convention on Climate Change. /convkp/kpeng.pdf.

UNFCCC, 1997b. National Communications, Communications from Parties Included in Annex I to the Convention, First Compilation and Synthesis of Second National Communications from Annex I Parties, Addendum, Tables of Inventories of Anthropogenic Emissions and Removals for $1990-1995$ and Projections up to 2020. FCCC/SBI/1997/19/Add.1. /1997/sbi/19a1.pdf. 
Dr Jari Liski is a research scientist at the European Forest Institute (EFI) in Finland. European Forest Institute, Torikatu 34, FIN80100 Joensuu, Finland, email Jari.Liski@efi.fi.

Dr Timo Karjalainen is a programme manager of forest ecology and management at EFI. European Forest Institute, Torikatu 34, FIN80100 Joensuu, Finland, email Timo.Karjalainen@efi.fi.

Ari Pussinen, MSc, is a research scientist at EFI. European Forest Institute, Torikatu 34, FIN-80100 Joensuu, Finland, email Ari.Pussinen@efi.fi.
Gert-Jan Nabuurs, MSc, is a research scientist at the Institute for Forestry and Nature Research in the Netherlands. Institute for Forestry and Nature Research, Postbus 23, NL-6700 AA, Wageningen, The Netherlands, email G.J.Nabuurs@ibn.dlo.nl.

Dr Pekka Kauppi is a professor of environmental science and policy at the University of Helsinki in Finland. Department of Limnology and Environmental Protection, P.O. Box 27, FIN-00014 University of Helsinki, Finland, email Pekka.Kauppi@helsinki.fi. 